\title{
EFFICIENT MARKETING CHANNELS AS PREREQUISITE FOR COMPETITIVENESS IN THE SERBIAN GAS BOILER MARKET
}

\author{
Dragoljub Jovičić" \\ Novi Sad School of Business, Novi Sad, Republic of Serbia \\ Marija Vranješ \\ Novi Sad School of Business, Novi Sad, Republic of Serbia \\ Dragana Gašević \\ Novi Sad School of Business, Novi Sad, Republic of Serbia
}

\begin{abstract}
In the last ten years, the Serbian gas boiler market has been intensively developing. Along with the increase in demand, the number of present brands increased, as well as the number of distributors who were engaged in the placement of products. Competition has become sharper, and only those distributors who had an efficient marketing mix could have a competitive advantage and provide survival on the Serbian market. In order to explore the importance of individual marketing mix instruments in placement of gas boilers in Serbia, authors preliminarily interviewed customers, experts - technical persons, sales managers, as well, who may well know this very complex problem. The research was based on a research hypothesis that reads: Efficient marketing channels represent a key factor for achieving competitive advantage in the Serbian gas boiler market. After field research, the collected data are processed by using appropriate methodology and the results of the survey confirmed the research hypothesis.
\end{abstract}

Key words: marketing channels, marketing mix, competitiveness, Serbian gas boiler market

JEL Classification: M31

*djovicic@uns.ac.rs 


\section{EFIKASNI MARKETING KANALI - PREDUSLOV ZA KONKURENTNOST NA SRPSKOM TRŽIŠTU GASNIH KOTLOVA}

Sažetak: U poslednjih deset godina intenzivno se razvijalo srpsko tržište gasnih kotlova. Paralelno sa porastom tražnje, povećavao se broj prisutnih brendova, ali $i$ broj distributera, koji su se bavili plasmanom ovih proizvoda. Konkurencija je postajala sve oštrija, i samo oni distributeri koji su imali efikasan marketing miks mogli su ostvariti konkurentsku prednost $i$ obezbediti opstanak na srpskom tržištu. Želeći da istraže značaj pojedinih instrumenata marketing miksa pri plasmanu gasnih kotlova u Srbiji, autori su preliminarno intervjuisali kupce, eksperte - tehnička lica, ali i menadžere prodaje, koji možda i najbolje poznaju ovu, veoma kompleksnu, problematiku. Istraživanje se zasniva na istraživačkoj hipotezi koja glasi: Efikasni marketing kanali su ključni faktor ostvarivanja konkurentske prednosti na srpskom tržištu gasnih kotlova. Nakon terenskih istraživanja, prikupljeni podaci su obrađeni primenom odgovarajuće metodologije, a rezultati istraživanja su potvrdili istraživačku hipotezu.

Ključne reči: marketing kanali, marketing miks, konkurentnost, srpsko tržište gasnih kotlova

\section{INTRODUCTION}

For the majority of marketing theorists, a product is undoubtedly the main, key marketing mix instrument, since, conditionally speaking, without a specific product, pricing policy may not be formed or maintained, there is nothing to promote, nor any need for the distribution and/or creation of marketing channels and marketing logistics. However, regardless of the product's dominant position in organizational marketing mixes, it occurs quite frequently that, depending on the type and purpose of the product, its life cycle, market situation, competition strength and an array of other relevant factors, other marketing mix instruments also play the key, even leading role in the successful placement of certain products, within certain time periods. This very conclusion has been reached by the authors of this paper based on long-term observation of the gas boiler market in Vojvodina and Serbia, where the influence of certain basic marketing mix instruments on the success of the placement of various gas boiler brands has changed significantly over time, due to fluctuations of market conditions. There have been periods when promotional activities, i.e., marketing communication (Fill, 2011; Jovičić, Vranješ and Stankov, 2015) have been 
58 I EFFICIENT MARKETING CHANNELS AS PREREQUISITE FOR COMPANY COMPETITIVENESS IN THE SERBIAN GAS BOILER MARKET

considered a key factor for the good positioning of certain gas boiler brands or certain distributors in the market of Vojvodina or Serbia, but there has also been a longer time period in which the product, i.e., its quality, functionality, energy efficiency, design, maintenance and warranty period have served as the key factors in customers opting in favor of a particular brand.

Upon analyzing the current situation in the Serbian gas boiler market, during the preliminary field work and prior to the official data collection through unstructured personal communication (Hair, Wolfinbarger, Oritinav and Bush, 2013) with relevant stakeholders in the procurement, promotion, placement, purchase, installation and exploitation of gas boilers, our impression was that all importers and/or distributors realized that there was quite little room for differentiation from competition in the field of products and pricing. It is quite onerous for any of the manufacturers to make a significant technical and technological advance in comparison to competition, and if that is the case, taking today's general globalization into account, such comparative advantage cannot be maintained in the long run, given that competitors quickly grasp and apply (imitate) current, state-of-the-art technological solutions. As regards pricing - as one of the main marketing mix instruments in the Serbian gas boiler market, it is more than obvious that all stakeholders on the supply side avoid "price wars" and that, for the last ten years, there has been no significant violation of the long-term, established price parity. Finally, although the possibility of a quick, or even instantaneous approach to an unlimited number of information and promotional messages has increased immensely due to a strong development of information technology and the Internet in particular, which was indeed impossible to be achieved via traditional media (Silverstein, 2002; Varey, 2002), promotion by itself is currently not strong enough and is not of crucial importance for the successful placement of gas boilers on the Serbian market.

Having all this in mind, although the most prominent manufacturers and distributors still make large investments in product planning and development, as well as in promotional activities, their focus in the current economic period is shifting more towards distribution, marketing channels and marketing logistics (Kotabe and Helsen, 2011) since it still provides enough room for the achievement of a competitive advantage. This has been the very motive for the preparation of this paper - to utilize field research and data collected from relevant stakeholders in the gas boiler market in order to investigate the significance and influence of certain basic marketing mix instruments on the success of the placement of gas boilers in the Republic of Serbia. 


\section{MARKETING CHANNELS IN THE SERBIAN GAS BOILER MARKET}

The growth of the Serbian gas boiler market was discontinuous and depended to a large extent on factors that affected the purchasing power of prospective gas boiler customers and/or users, as well as a number of other relevant market factors. One should bear in mind the fact that gas boilers are quite complex products in technical terms and that their price ranges from several hundred to several thousand Euros, depending on brand and capacity. In line with this fact, supply was more or less abundant in comparison to demand. There were certain periods when only a handful of brands were offered and could only be purchased in larger cities within the territory of the Republic of Serbia, in few retail stores. At the moment, supply is significantly better, approximately ten brands are offered in the market, with varying price levels - which generally, in an objective manner, reflect the quality, functionality and energy efficiency of the product and brand familiarity, i.e. its image. The efficiency of marketing channels has improved greatly, while the number of distributors and retailers which have developed powerful distribution systems and which offer gas boilers is much higher, meaning that prospective customers may use much less effort and consume less time in procuring the desired products (Clow and Baack, 2012). The most prominent and thus the most frequently sought after brands of boilers in the domestic market are the following: "Vaillant", "Remeha", "Protherm", "Bosch", "Beretta", "Immergas", "Buderus", "Bergen", "Baxi". Without a doubt, it can be concluded that, for more than a decade, "Vaillant" has been maintaining its primacy in the market by holding by far the largest market share; however, due to increasingly stronger and agile competition, its market share percentage in the Serbian market has decreased from previous 40$45 \%$ to current $30-35 \%$. For the last couple of years, its most serious competitor has been "Remeha", which has utilized its well-organized and efficient marketing channels, proper service maintenance and dynamic two-way communication with customers to significantly increase its market share level and become the market runner-up. In addition, notable quantities of "Protherm" and "Bosch", and, to a lesser extent, gas boilers of other brands are being positioned in the market of the Republic of Serbia.

As regards the theoretical aspect of marketing channels, one could say that distribution, as one of the four basic marketing mix instruments, has two dimensions - creating and/or selecting marketing channels and marketing logistics, where the marketing channel strategy is far more complex and demanding in comparison to marketing logistics, which deals with physical movement, transport and storage of goods (Rosenbloom, 1999). In this context, 
60 I EFFICIENT MARKETING CHANNELS AS PREREQUISITE FOR COMPANY COMPETITIVENESS IN THE SERBIAN GAS BOILER MARKET

marketing channels are most frequently described in professional literature as a set of mutually dependent organizations involved in the process of creating products or services and their accessibility, i.e. availability for use or final consumption (Coughlan, Anderson, Stern and El-Ansary, 2001). In order for marketing channels and marketing channels used for the placement of gas boilers on the Serbian market to function in an efficient manner, their structures should be consisted of qualified and competent institutions (Rosenbloom, 1999), i.e. specific channel members that will perform a variety of activities necessary for the goods to quickly and safely cross the path from the factory hall to the end user. In the majority of cases, manufacturers or large intermediaries, as primary channel members, play the marketing channel leader role, select channel members, establish and maintain diverse channel links among channel participants, and in doing so strive to ensure that each channel member is satisfied and adequately rewarded for its work and contribution to the successful functioning of the channel (Lovreta, Končar and Petković, 2005). However, although the marketing channel leader role is mainly played by one of the larger and financially more powerful channel members, with authority and certain power, conflict situations may often arise in relation to the distribution of channel operations, specifying priority objectives, share in rebates or margins and the like; therefore, regardless of how strong it may be, it is far from easy for the channel leader to provide a good and fair climate among channel members, continuous and effective channel functioning and good positioning of the organization in the market (Kotler, Wong, Saunders and Armstrong, 2007). From all of the above, it may be concluded that the channel leader role is not an easy one, but quite on the contrary - when speaking of gas boiler marketing channels, it must be borne in mind that, in addition to basic, primary institutions and common auxiliary institutions such as banks, insurance companies, freight forwarders, carriers and the like, there are also several other participants in the form of specific auxiliary institutions such as design bureaus and assemblers, which additionally complicates the already largely complex work of the marketing channel leader in the Serbian gas boiler market (Jovičić, 2011). As regards the length of marketing channels in our market, in practice and in addition to direct and indirect marketing channels, it is not seldom to use a combination of these two models which, given the marketing flow movement within the channel, may be deemed as virtual direct or quasi-direct marketing channels (Jovičić, 2012). These channels are usually applied in cases of large quantities of gas boilers; therefore, in order to achieve time, transportation and storage cost savings, goods are shipped directly from the manufacturer and importer to the end user or investor.

Bearing in mind the fact that there are no more credible domestic gas boiler manufacturers in our market, it is utterly clear that, when creating marketing 

channels for the placement of gas boilers on the Serbian market, renowned foreign manufacturers or large importers are required to engage commercially and financially strong channel participants, distributors which will efficiently store, promote and market these products. Taking into account the opinion of certain marketing theorists, pursuant to which product marketing channels are longer than service ones (Kurtz and Clow, 1998), it is evident that channel leaders in the Serbian gas boiler market will be forced to create longer channels with more members, i.e. more channel participants, whereby they will be obliged to pay maximum attention to their image, expertise and qualifications during the process of their selection, in order to ensure their ability to perform their work within the specific marketing channel in a high quality and efficient manner, and thus contribute to the successful placement and good positioning of that particular brand in the Serbian market.

The analysis of the structure of customers and/or users of gas boilers has identified an extremely wide range of those interested in purchasing and using these products. A vast number of boilers are purchased by natural persons, but also a major number of customers consist of legal entities such as various industrial, transport, agricultural organizations as well as entities from educational, religious and other institutions (Galogaža, 1999). Given that prospective gas boiler customers are quite heterogeneous in terms of their activities, sizes, financial strength and other criteria, gas boiler importers and distributors are facing an arduous task of offering an optimal marketing mix variant, adapted to their needs and possibilities, i.e. offering greater value as compared to that offered by competitors (Porter, 1998). In order to manage this, channel leaders that usually come from importers or large distributors, must have a good knowledge of the market and its prospective customers above all, as well as of their competitors and the situation on the energy market, provide a fair warranty period, professional and efficient maintenance of their products, and last but not least, comprehend and monitor the entire purchasing process experienced by prospective customers. Purchasing is not merely a one-off act of exchanging money for goods, but quite the contrary, especially in case of purchasing higher value goods such as gas boilers, where it represents a long lasting process, starting from becoming aware of the need for a specific product, through the collection of information from several various sources and estimating the existing alternatives, until the very purchase and post-purchase period. For presenting the purchasing process, professional literature in general includes the use of a classic purchasing decision-making model consisting of five steps, but there are certain authors who have broadened this five-stage model by introducing more stages (Blackwell, Miniard and Engel, 2001), although the essence itself has remained the same, and therefore sellers in our market must be aware that gas boiler customers undergo a long process of 
62 I EFFICIENT MARKETING CHANNELS AS PREREQUISITE FOR COMPANY COMPETITIVENESS IN THE SERBIAN GAS BOILER MARKET

deliberating, collecting and processing relevant information in order to reduce the risk of bad purchases, and ultimately opt for a variant deemed as optimal at the given moment, by choosing the highest value options for themselves.

\section{RESEARCH METHODOLOGY}

During the collection and processing of data within the research process, we conducted parallel desk and field researches. Quantitative field research was carried out in May and June 2018, covering the Belgrade and Novi Sad areas. The method of deliberate selection of respondents from importers, intermediaries, designers, assemblers and investors who were well acquainted with the issues of promotion, procurement, design, sale, distribution, purchase, installation and exploitation of gas boilers, was used in order to form a representative sample. The selection included persons with sufficient expertise and work experience (experts) able to provide relevant answers to the questions asked via unstructured personal communication. Interviewing respondents in the field required a very tactful and cautious approach, since many respondents did not want to be involved in "deeper" conversations or to provide more detailed and up-to-date information that, in their opinion, could imperil their current market position. Being well aware that competition in the market was immensely harsh, we were understanding of their attitudes on this issue, but this did not affect the scope and quality of the relevant data obtained from them during field work.

The research was based on a research hypothesis that reads: Efficient marketing channels represent a key factor for achieving competitive advantage in the Serbian gas boiler market.

For a better and more thorough understanding of the research hypothesis, it should be emphasized that marketing channels represent extremely complex issues which encompass their length, intensity, flows and institutions (Kotler, Wong, Saunders and Armstrong, 2007; Jovičić and Sudarov, 2014), as well as all of the numerous functions performed in the channel by various participants (channel members), such as purchasing, selling, transporting, storing, financing, informing, risk undertaking and the like (Mooradian, Matzler and Ring, 2012; Sims, Foster and Woodside, 1977). It was this very complexity and multidimensionality that provided significance for marketing channels and this is probably why the majority of merchants from this field primarily emphasized the exceptional importance of efficient marketing channels for the successful placement of gas boilers and good positioning in the Serbian gas boiler market. 


\section{DISCUSSION OF RESEARCH FINDINGS}

Data were collected in large urban areas, where the largest distributors of gas boilers were located. In addition to the distributors, certain importers, designers, assemblers (responsible contractors, supervisory authorities) and investors (customers) also stationed in cities were interviewed as well. The field collection of data was followed by desk research. Prior to presenting the findings, and considering the fact that we have been dealing with the issue of gas boilers and research related to their placement for nearly a decade, we would like to point out that the relative relationship between certain marketing mix instruments has changed over time, depending on the current influence of a series of relevant factors in the gas boiler market (Jovičić, 2013). At the very beginning, when the first gas boilers were introduced to our market, promotion played a very important role and accomplished quite difficult and complex, pioneering tasks of informing, educating, convincing and persuading prospective customers, in order to familiarize them with all relevant characteristics, manner of operation, exploitation and comparative advantages of gas boilers compared to other spatial heating alternatives using coal, wood, oil, electricity etc. as energy sources. For a longer period of time, the product itself, i.e. its quality and performance, was a key marketing mix instrument serving as the crucial factor when making a decision to buy gas boilers. This being said, one of the motives for this research is the desire to obtain relevant information which will demonstrate the current relative relationship between the basic marketing instruments in the domestic gas boiler market.

Table 1 contains the data, i.e. views of 15 relevant respondents - professionals, experts in the sale, purchase and exploitation of gas boilers. They expressed their views on the current state of the Serbian gas boiler market using a 1 to 5 rating, where 1 is an extremely negative and 5 is an extremely positive view regarding certain basic marketing mix instruments, i.e. attitude on their significance and influence on the successful placement of gas boilers.

Pursuant to the data presented in Table 1, it is evident that the respondents accorded extremely great importance to the product (4.33) and distribution, i.e. marketing channels (4.46) in the placement of gas boilers on the Serbian market. Significantly lower average ratings were given to pricing (3.60) and promotional activities (2.13). Considering the fact that the difference between the average product rating and distribution rating is quite small, further analysis was undertaken in order to confirm the minimal advantage of marketing channels over the product. 
64 I EFFICIENT MARKETING CHANNELS AS PREREQUISITE FOR COMPANY COMPETITIVENESS IN THE SERBIAN GAS BOILER MARKET

Table 1

Relative significance of basic marketing mix instruments in the placement of gas boilers on the Serbian market

MARKETING MIX INSTRUMENTS

\begin{tabular}{|c|c|c|c|c|}
\hline RESPONDENTS & $\begin{array}{l}\text { PRODUCT } \\
\text { (quality, } \\
\text { functionality, } \\
\text { design...) }\end{array}$ & $\begin{array}{l}\text { PRICE } \\
\text { (rabat, bonus, } \\
\text { credit...) }\end{array}$ & $\begin{array}{l}\text { PLACE } \\
\text { (marketing } \\
\text { channels, } \\
\text { marketing } \\
\text { logistics) }\end{array}$ & $\begin{array}{l}\text { PROMOTION } \\
\text { (economic } \\
\text { propaganda, } \\
\text { sales } \\
\text { improvement...) }\end{array}$ \\
\hline 1 & 4 & 3 & 4 & 3 \\
\hline 2 & 4 & 4 & 5 & 3 \\
\hline 3 & 5 & 3 & 4 & 4 \\
\hline 4 & 4 & 3 & 5 & 3 \\
\hline 5 & 4 & 4 & 4 & 3 \\
\hline 6 & 4 & 3 & 4 & 3 \\
\hline 7 & 5 & 4 & 5 & 3 \\
\hline 8 & 4 & 4 & 5 & 4 \\
\hline 9 & 5 & 5 & 4 & 3 \\
\hline 10 & 5 & 4 & 4 & 3 \\
\hline 11 & 4 & 3 & 4 & 2 \\
\hline 12 & 4 & 3 & 5 & 3 \\
\hline 13 & 4 & 3 & 4 & 4 \\
\hline 14 & 5 & 4 & 5 & 3 \\
\hline 15 & 4 & 4 & 5 & 3 \\
\hline Total & 65 & 54 & 67 & 47 \\
\hline Average & 4,33 & 3,60 & 4,46 & 3,13 \\
\hline Standard Deviation & 0,2108 & 0,2697 & 0,1819 & 0,2045 \\
\hline $\begin{array}{l}\text { Coefficient of } \\
\text { Variation }(\%)\end{array}$ & 4,86 & 7,49 & 4,07 & 6,53 \\
\hline
\end{tabular}

Note. Calculated by the authors. 
Upon observing the data in Table 1, it can be noted that the data calculated for standard deviation and coefficient of variation confirmed the representativeness of the average ratings, and that distribution, i.e. marketing channels (standard deviation of 0.1819 and coefficient of variation of $4.07 \%$ ) have a mild yet indisputable advantage over the product (standard deviation of 0.2108 and coefficient of variation of $4.86 \%$ ) and that in this market constellation, when the research was conducted, marketing channels represented the most important marketing instrument in the Serbian gas boiler market.

It has unequivocally been established that, according to experts engaged by importers, distributors, assemblers and investors, efficient marketing channels are the crucial and dominant marketing mix instrument, which in the current business environment enables organizations to gain competitive advantage and become well positioned in the turbulent Serbian gas boiler market.

\section{CONCLUSION}

In modern market business, where competition has become global, nearly all companies operate under very uncertain and turbulent conditions, in constant confrontation with their competitors to realize or at least follow modern technological achievements at the earliest, and to create an optimal marketing instrument combination, with simultaneous efforts to fully satisfy the needs and desires of their customers and/or consumers, who are becoming increasingly educated and informed, and therefore more demanding and fastidious. Considering the fact that, for the last ten years, the Serbian gas boiler market has been experiencing immense development and growth, it is quite logical that the competition among importers and distributors of these products has become quite fierce. Intense competition unquestionably imposes continuous and effective battle against competitors for all market participants on the supply side, in order to ensure a better market position. In this context, the key research problem during the preparation and work on this research appeared in the form of a question - how to ensure and maintain competitive advantage in the Serbian gas boiler market?

The aim of the research has been to prove that all marketing instruments are significant, but that efficient marketing channels are the key marketing mix instrument in gaining competitive advantage in the Serbian gas boiler market. The research process findings indicate that the research hypothesis should be accepted and that, in the relevant respondents' opinion, efficient marketing channels are the crucial and dominant marketing mix instrument, which in the current business environment enables organizations to gain competitive advantage and become well positioned in the rather uncertain and turbulent Serbian gas boiler market. 
66 I EFFICIENT MARKETING CHANNELS AS PREREQUISITE FOR COMPANY COMPETITIVENESS IN THE SERBIAN GAS BOILER MARKET

The research findings may have significant practical implications for managers and marketers engaged by gas boiler importers and distributors, in order to make timely and optimal business decisions based on relevant information when creating ("dosing") marketing mix instruments, which will most certainly contribute to better positioning of their organizations in the Serbian gas boiler market. These findings may also serve to all market stakeholders on the gas boiler supply side as a solid basis for formulating a market strategy and creating an optimal marketing mix. It would be rather interesting and advantageous for distributors to deepen the analysis related to marketing channels in future researches, as well as to investigate the importance of certain institutions and flows in marketing channels in the placement of gas boilers. In addition to the global conclusion regarding the importance of marketing channels in the placement of gas boilers, this could be used for a more rigorous identification of the significance of basic and/or auxiliary institutions (channel members), as well as the significance of particular flows in specific marketing channels in the placement of gas boilers in the Serbian market.

\section{REFERENCES}

Blackwell, R. D., Miniard, P. W., \& Engel, J. F. (2001). Consumer Behavior. The Dryden Press.

Clow, K., \& Baack, D. (2012). Cases in Marketing Management. Los Angeles: Sage.

Coughlan, T. A., Anderson, E., Stern, W. L., \& El-Ansary, I. A. (2001). Marketing Channels. New Jersey: Prentice Hall.

Fill, C. (2011). Essentials of Marketing Communications. Harlow: Pearson Education Limited.

Galogaža, M. (1999). Industrijski marketing. Novi Sad, Republika Srbija: Marketing Management College.

Hair, F. J., Wolfinbarger, C. M., Oritinav, J. D., \& Bush, P. R. (2013). Essentials of Marketing Research (3rd edition). New York: McGrawHill.

Jovičić, D. (2011). Specifične institucije marketing kanala pri plasmanu gasnih kotlova na tržištu Republike Srbije. Škola biznisa, 3, 116-123.

Jovičić, D. (2012). Dužina marketing kanala pri plasmanu gasnih kotlova. Škola biznisa, 1, 102-112.

Jovičić, D. (2013). Uloga montažera termo-tehničkih instalacija pri kupovini gasnih kotlova. Marketing, 44(4), 361-371. 
Jovičić, D., \& Sudarov, S. (2014). Savremeno tržišno poslovanje. Novi Sad, Republika Srbija: Alfa-graf NS.

Jovičić, D., Vranješ M., \& Stankov B. (2015). Sticanje konkurentske prednosti na vojvođanskom tržištu gasnih kotlova putem integrisanih marketing komunikacija. Škola biznisa, 1, 153-171.

Kotabe, M., \& Helsen, K. (2011). Global Marketing Management. John Wiley $\&$ Sons, Asia.

Kotler, F., Vong, V., Sonders, Dž., \& Armstrong, G. (2007). Principi marketinga. Beograd, Republika Srbija: Mate.

Kotler, P., \& Keller, K. L. (2006). Marketing menadžment. Beograd, Republika Srbija: Data status.

Kurtz, L.D., \& Clow, E. K. (1998). Services Marketing. New York: John Wiley $\&$ Sons.

Lovreta, S., Končar, J., \& Petković, G. (2005). Kanali marketinga. Beograd, Republika Srbija: Centar za izdavačku delatnost Ekonomskog fakulteta u Beogradu.

Malhotra, N. K., Birks, D. F., \& Wills, P. (2012). Marketing Research. Harlow: Pearson.

Mooradian, T. A., Matzler, K., \& Ring, L. J. (2012). Strategic Marketing. Pearson, Prentice Hall.

Porter, M. E. (1998). Competitive Strategy. New York: Free Press.

Porter, M. E. (2008). Konkurentska prednost,. Zagreb, Republika Hrvatska: Masmedia.

Rosenbloom, B. (1999). Marketing Channels. Orlando: The Dryden Press.

Silverstein, B. (2002). Business to Business Internet Marketing. Florida: Maximum Press.

Sims, J. T., Foster, J. R., \& Woodside, A. G. (1977). Marketing channels (Systems and strategies). New York: Harper \& Row.

Varey, R. J. (2002). Marketing communication. London: Routledge. 